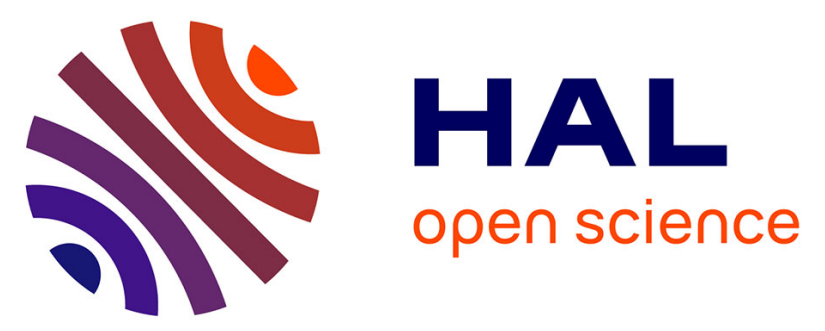

\title{
The key roles of economic and social organization and producer and consumer behaviour towards a health-agriculture-food-environment nexus: recent advances and future prospects
}

Alban Thomas, Claire Lamine, Benjamin Allès, Yuna Chiffoleau, Antoine

Doré, Sophie Dubuisson-Quellier, Mourad Hannachi

\section{To cite this version:}

Alban Thomas, Claire Lamine, Benjamin Allès, Yuna Chiffoleau, Antoine Doré, et al.. The key roles of economic and social organization and producer and consumer behaviour towards a health-agriculturefood-environment nexus: recent advances and future prospects. Review of Agricultural, Food and Environmental Studies, 2020, 101 (1), pp.23-46. 10.1007/s41130-020-00115-x . hal-02945924

\section{HAL Id: hal-02945924 \\ https://hal.inrae.fr/hal-02945924}

Submitted on 9 Aug 2021

HAL is a multi-disciplinary open access archive for the deposit and dissemination of scientific research documents, whether they are published or not. The documents may come from teaching and research institutions in France or abroad, or from public or private research centers.
L'archive ouverte pluridisciplinaire HAL, est destinée au dépôt et à la diffusion de documents scientifiques de niveau recherche, publiés ou non, émanant des établissements d'enseignement et de recherche français ou étrangers, des laboratoires publics ou privés.

\section{(c)(1)}

Distributed under a Creative Commons Attribution| 4.0 International License 


\title{
The key roles of economic and social organization and producer and consumer behaviour towards a health-agriculture-food-environment nexus: recent advances and future prospects
}

\author{
Alban Thomas ${ }^{1}$ (D) . Claire Lamine ${ }^{2}$. Benjamin Allès ${ }^{3} \cdot$ Yuna Chiffoleau $^{4}$. \\ Antoine Doré ${ }^{5} \cdot$ Sophie Dubuisson-Quellier ${ }^{6}$ - Mourad Hannachi ${ }^{7}$
}

Received: 11 November 2019 / Accepted: 25 June 2020 / Published online: 4 August 2020

(C) INRAE and Springer-Verlag France SAS, part of Springer Nature 2020

\begin{abstract}
We discuss in this paper the role of the economic and social organization in agriculture and the food industry, in relation with the Health-Agriculture-FoodEnvironment (HAFEN) concept. The aim is to better understand the potential impact of the implementation of this concept in food consumption and production systems in terms of research needs. The paper suggests a research agenda dedicated to the modes of social and economic organization of key stakeholders in the implementation of nexus-based systems, facilitating the convergence among health, food and environmental objectives. Based on a literature survey, three main topics are discussed: (a) processes and drivers of change of food consumption practices; (b) coordination and multi-agent governance modes to better account for health issues in agrifood systems and (c) the analysis of paradigms that put forward health as an entry point to reshape existing agricultural and food systems, and associated modes of knowledge production. For each of these topics, we suggest a selection of research priorities for the future and conclude with methodological perspectives on the HAFEN.
\end{abstract}

Keywords Nexus $\cdot$ Food system $\cdot$ Health $\cdot$ Social and economic organization $\cdot$ Behaviour

This paper originates from a working group of the collective foresight study on health and food nexus at INRAE (French National Research Institute for Agriculture, Food and the Environment, formerly INRA) that was carried out in 2018 and early 2019. We thank Stephan Marette and two anonymous reviewers for their helpful comments. Alban Thomas acknowledges funding from ANR under grant ANR-17-EURE-0010.

Alban Thomas

Alban.Thomas@inrae.fr

Extended author information available on the last page of the article 


\section{Introduction}

Scientific evidence on the multiple impacts of current farming and food systems, as well as the rise of alternative ways of producing and consuming food, point to the need to better connect the different objectives associated with health, food, agriculture and the environment (Hammond and Dubé, 2012; Marsden and Sonnino 2012; Duru et al. 2017, Gordon et al. 2017). Reconnecting health, agricultural, food and environmental objectives is no easy task and in fact, most conceptual approaches combine challenges two by two: agricultural and environmental questions (with a diversity of paradigms such as "ecologically-consistent" agricultural models); agricultural and food issues with the development of food-system approaches; food and health questions with thriving nutritional models; and finally, environmental and health issues (with e.g. the notion of global health, see Lamine et al. 2019). Such a need for a better connection is also debated in local and international institutions (Burlingame and Dernini 2012; UN 2015), in line with a growing literature calling for a more integrated approach of food systems, instead of partial and fragmented views proposed by various scientific disciplines (Lamine et al. 2019). In this regard, a first integrated conceptual framework is the "One Health" concept which aims to link environment, agriculture (including animal breeding) and human health (Frazzoli and Mantovani 2019). The concept of One Health was created in the early 2000s and originates from the "One Medicine" concept that "advocates a combination of human medicine and veterinary medicine in response to zoonoses" (Destoumieux-Garzón et al. 2018). This concept carries a significant novelty: "the incorporation of the eco-system health, including that of wild fauna. The One Health concept therefore constitutes a global strategy highlighting the need for an approach that is holistic and transdisciplinary and incorporates multisector expertise in dealing with the health of mankind, animals, and ecosystems" (Destoumieux-Garzón et al. 2018). A second type of integrated conceptual framework is the "Nexus" concept that has originally been suggested to examine waterfood-energy interactions (Cairns and Krzywoszynska 2016) and the role of science, policy and practices interactions in sustainable food systems (Ipes-Food 2015). The nexus concept acknowledges the fact that components of food systems are mutually reinforcing, deeply interconnected and subject to systemic dynamics, as in the notion of "Food-Health nexus" (Ipes-Food 2017). We introduce in this paper the expression HAFEN to the application of this concept to Health-Agriculture-Food-Environment interactions and reconnection (Nexus).

Other integrated approaches exist which aim at taking into account this necessary reconnection, such as socio-ecological approaches (Gordon et al. 2017; Vallejo-Rojas et al. 2016), socio-metabolistic approaches (Fischer-Kowalski et al. 2011) and sociotechnical systems approaches (Dedeurwaerdere and Hannachi 2019). However, environmental and sustainability challenges are much more central in these approaches than health-related ones, even though they are both integrated in the definition of a sustainable diet proposed by the FAO. Moreover, as underlined by recent IPES Food reports (2015, 2017 and 2018, see also Ericksen et al. 2010), the role of governance, coordination, power, knowledge transmission and controversies over visions of necessary transitions (of food systems towards sustainability) is generally underplayed in the literature, whether the focus is more on health (like in the One Health concept) or on the environment (like in the above approaches). A possible explanation is that results from 
social studies are not always integrated in decision processes made by stakeholders, following debates about these issues.

In this paper, we propose to bridge this gap by providing an analysis of recent advances in social sciences (but also epidemiological studies where research questions emerging from social sciences are considered), which addresses the role of social and economic organization and of producers' and consumers' behaviour in food system transitions. In this perspective of the HAFEN, a bibliographical analysis (mainly focused on the last 5 years) enabled us to identify major topics in the literature (mostly in economics, management and sociology). This includes mechanisms underlying changes in:

- Processes and drivers of change in food consumption;

- Coordination and multi-agent governance modes in food systems;

- Health-related paradigms and associated knowledge production modes.

Our analysis reveals that on the first two topics, a vast research is available in social sciences, with a growing interest on environmental issues, although less on health. The last topic appears less explored but is in fact essential to better understand in what way the concept of nexus connecting health, food, agriculture and the environment may change the research practices and the visions of sustainability. A collective work through an iterative process allowed us to prioritize a series of six research priorities, as well as to highlight the need to tackle an issue that has also been overlooked in the scientific literature, that of welfare and health (including human health at work).

The paper is structured as follows. "Introduction", "Processes and drivers of change in food consumption" and "Coordination and multi-agent governance modes to better account for health and sustainability in food systems" summarize research advances on the three topics introduced above i.e. processes and drivers of change in food consumption, co-ordination and multi-agent governance modes in food systems, the HAFEN-related paradigms and associated modes of knowledge production. In every section, beyond describing the state of the art, research priorities are suggested with the aim to better include health issues in food system research. We also provide a focus on a specific research programme as an illustration for each topic (section). Finally, the conclusion will address some methodological priorities linked to the aforementioned research issues.

\section{Processes and drivers of change in food consumption}

We provide in this section a literature review on the first topic, processes and drivers of change in food consumption, before suggesting a set of research priorities. There is a variety of such drivers that are not limited to standard variables such as prices and household income, especially when transition to more sustainable and healthier food practices is at stake. Quality differentiation processes, labelling, public health and/or environmental recommendations are among the drivers that have started to receive attention especially in economical approaches. Sociologists have on their side investigated more the construction of norms and their socially differentiated impacts, consumers' representations and trajectories of change, as well as the impact of the material 
environment on their practices and the role of social networks in changes of visions and practices.

In economics, there exists a vast literature that sets the standards of the identification of drivers behind consumer demand for food. Beyond key variables such as prices and household income, economic models of food consumption have tried to measure the relative role of the characteristics of food items on consumer demand (see the literature review by Irz et al. 2015). On the theoretical side, a wide range of research has been devoted to the understanding of differentiation processes in food products and the transmission of information to consumers (see Bonroy and Constantatos 2015; Bacchiega, Bonroy and Petrakis 2018; and Bazoche et al. 2013, on the special case of organic food). On the empirical side, the literature has quantified the links between quality characteristics and the price of quantity demanded, for various agrofood chains (see for instance Hassan and Monier-Dilhan 2006 on labels). The objective is to evaluate the impact of differences in product quality on demand and on the price of these products, for consumer analysis and policy recommendation purposes. Such evaluation is mostly concerned with nutritional contents of food in the existing literature, and it also includes sanitary conditions, although this dimension is less visible from the consumer side. Some important results in this literature are that, following food safety crises, food firms have developed product differentiation strategies to meet preferences of consumer segments. The latter involves subjective knowledge of consumers over food quality that are closer to consumer values than objective characterization of food quality (Irz et al. 2015). On the empirical side, the nature and contents of information to consumers have been shown to play a major role, especially in markets with strong scientific uncertainties and numerous product innovations. Moreover, consumers tend to place more importance on labels of origin than on private brands, emphasizing the symbolic role of food in relation to subjective quality.

Experimental economics (in the lab or on the field) is a way of analysing the impact of product information in general, and labelling in particular, on consumption decisions (Marette et al. 2012; Barlagne et al. 2015; Julia et al. 2016), which can be applied to health and environmental risks associated with a food product. From stated preference methods, one can obtain a fairly good precision on the willingness to pay (WTP) for product characteristics associated with health, the environment, food security, etc. (Bougherara and Combris 2009; Lusk and Shogren 2007). More recent research addresses the evaluation of the WTP for different dimensions of sustainable food systems: ethical and responsible consumption, reduction of sanitary risk (Andersson et al. 2015) and the role of psychological determinants in purchasing decisions, etc. As discussed in Irz et al. (2015), experimental methods in economics have provided major advances in the analysis of consumer behaviour, but they may still require integration with neoclassic economics to yield a more robust understanding of consumer decisions and of public policy impacts. Given the importance of this research in assessing drivers of change in food consumption, we consider it a research priority, see RP1 below.

Another key issue is the impact of public health and/or environmental recommendations. Research in public economics applied to food consumption (Leroy et al. 2016; Irz et al. 2016) has evaluated the impact of nutritional or environmental recommendations in several European countries (European project EraNet SusDiet). The impact of these recommendations is shown to be very heterogeneous and difficult to compare from one country to another. Communication policies seem to have a favourable 
benefit-cost ratio, with significant spillover effects when a recommendation campaign is targeting a particular goal (promotion of fresh products in the diet, salt contents, environmental impact, etc.). Recent research in sociology on the reception of health and food standards (Plessz et al. 2014) suggests that the working class would be less likely to adhere to official nutritional or environmental guidelines (e.g. ANSES 2017), despite their notoriety, because of the distance to current practices and a lower confidence level regarding expert sources (Marty et al. 2015). Indeed, there is a need for further research about how specific social groups within the population choose to adhere or not to nutritional or environmental guidelines.

New incentive-based mechanisms such as Nudges also give way to an expanding literature in economics (see Croson and Treich 2014; Schubert 2017). They are designed to modify agents' behaviour at a least cost, through a mere presentation of different situations without modifying the choice set and without economic incentives (Thaler and Sunstein 2008). Recent research in sociology has, however, shown the limits of such approaches as well as the socially contrasted effects of a policy targeting only behaviour (Dubuisson-Quellier 2016; Wahlen and Dubuisson-Quellier 2018; Gumbert 2019).

Other sociological studies address the construction of norms and have shown the diversity of private and public stakeholders (industrialists, associations, health professionals, etc.) involved in such construction (Depecker et al. 2013). Organizations that represent the interests of food industries, such as salt (Déplaude 2015) or alcohol (Fortané, 2016) producers, act strategically to influence the design of public policies or to develop lobbying strategies through charities and philanthropic actions (Depecker et al. 2018).

In social psychology, sociology and anthropology, the analysis of consumer representations and practices represents a relatively well-structured research field. In psychology, there is a general consensus that the causal link between agents' representation and practices is a complex one, in particular, because of cognitive dissonance phenomena (see the reviews by Martin and Gaspard 2016 and Swee-Jin Ong et al. 2017). In sociology and anthropology, representations are considered to be built in and from current practices, along eaters' trajectories and in social networks, and "alternative" knowledge and skills about food are shaping themselves therein. Many studies have focused on consumers' transitions towards vegetarianism (Beardsworth and Keil 1991), organic food and "vegetarization" trends (Lamine 2003, 2008) and more recently on "vegetarized" behaviour involving reduced consumption of animal products, from "flexitarism" to "vegetalism" and "veganism" (Mouret 2016).

Recent research in sociology has shifted to a focus on practices, emphasizing how food practices refer to skills, norms or time (Plessz and Etile 2018; Plessz and Gojard 2015). In the particular stream of practice theory, scholars have assessed the role of routines, materiality, norms and time constraints in shaping food practices (Warde and Yates 2017). Some of these studies stress the importance of understanding inertia in food practices (Wahlen 2011) and the persistent effect of social differentiation, whether related to fruit and vegetable consumption (Plessz and Gojard 2013), obesity or anorexy (Régnier and Masullo 2009), an effect also illustrated by research in nutrition (Darmon 2003). Diverse social determinants generate this social differentiation of food practices, such as the role of inter-individual networks and social trajectories (Plessz and al. 2016) and of collective dimensions (Wahlen and Dubuisson-Quellier 2018). 
While most research in socio-anthropology has dealt with consumers already "out of bounds" from markets and food (organic food, vegetarism, etc.), recent work in sociology of food has highlighted the conditions for the adoption of sustainable or healthy food practices (Paddock 2017).

Another stream in the literature investigates the impact of "alternative" food systems (such as local food networks) on consumption habits as well as on the perception of food quality and its links with health and environmental dimensions (Goodman et al. 2011). Research addresses the way such networks may represent a place for public debate and collective learning on the combination of challenges associated with food (DubuissonQuellier et al. 2011). However, these networks often remain restricted to certain social categories and sometimes tend to impose their vision over others (Lamine 2011). In this light, further research should focus on the role of local food networks in the construction of sustainable consumption by "ordinary" consumers, particularly through learning processes associated to inter-individual relations (Chiffoleau et al. 2017).

The researches mentioned above share a common feature, namely the issue of social accessibility to quality food, which involves two different approaches: one in terms of "food justice" (Gottlieb 2009) and a second in terms of "food democracy" (Hassanein 2003; Chiffoleau et al. 2020). The impact of novel social experiments, regarding, in particular, processes of change in stakeholder visions and learning, is beginning to be analysed through action-research approaches, aimed at fostering changes in food practices and at evaluating them with the stakeholders (through e.g. food solidarity networks, see Paturel and Ramel 2017). An assumption to explore further, which has been the subject of early research (Le Velly and Paturel 2013), is that specific mechanisms are necessary to address the challenge of social accessibility to quality food, combining social experiments targeting poor and/or diversified households and adequate public policies.

\section{Box 1 The French NutriNet-Santé cohort study: an innovative participatory research platform for providing new knowledge about sustainable food consumption The} French NutriNet-Santé prospective cohort study that recruited more than 160,000 voluntary participants since 2009 has become a valuable source of information to study the relationship between nutrition and health outcomes - a major component of sustainability according to FAO (2010) — and also other determinants of food behaviour (Hercberg et al. 2010; Finkelstein et al. 2019). On-going studies bringing together social science and/or epidemiology and public health research teams are exploring not only the links between socio-demographic and food profiles and health but also environmental impacts of food consumption practices that are considered more sustainable. Although the prevalence of vegetarianism is still very low in France, this cohort provides an opportunity to apprehend a good variety of diets, from partial animal product exclusions such as pesco-vegetarianism or vegetarianism with consumption of milk and eggs, to full animal product exclusion such as veganism or strict vegetarianism. These studies also aim to identify motives and socio-demographical, economic, geographic, psychological determinants for the consumption (Méjean et al., 2016) or the eviction (Allès et al. 2017b) of animal products. Other works have evaluated the sustainability related motives of consumers in the general population (Allès et al. 2017a; Baudry et al. 2017; Péneau et al. 2017). Epidemiological approaches are also carried out on specific populations such as patients with chronical pathologies (Fassier 
et al. 2018; Adriouch 2017). Data from the NutriNet-Santé cohort are also currently being used in on-going research, with the objective to better understand food supply profiles through local food networks and their connections to health (through e.g. consumer motivation for purchase). Examples in France include the project on the rebalancing of plant and animal proteins (see e.g. Colombet et al. 2019), coordinated by INRAE. The BioNutrinet study, a research project included within the NutriNet-Santé cohort that started in 2014, is exploring the health and environmental impacts of organic food consumption (Seconda et al. 2018).

\section{Research priority 1: evaluating the willingness to pay for sustainable food}

Based on our literature review, the first research priority we suggest is to identify in an accurate manner the distribution of the willingness-to-pay (WTP, the maximum value - amount of their income — potential buyers are ready to forego to buy a unit of a good) for a sustainable food system. This is an essential step in the analysis of demand on existing markets (revealed preferences) or potential markets (stated preferences) as determinants of demand progressively include more and more drivers in relation with the HAFEN components (in particular, sustainability and food security). With the exception of well-identified sectors such as organic agriculture, labelling of sustainability dimensions on food products remains an important challenge for a satisfactory valuation of environmental benefits provided by producers. Experimental economics methods are making rapid progress towards a more accurate evaluation of WTPs for these different dimensions, also controlling for differences in socio-demographic factors (segmentation of the population). The number of scientific references in terms of products and their characteristics remains, however, too limited, so that an analysis of the total economic value associated with food products from "sustainable" food systems would be premature. Nevertheless, methods of transfer or a finer segmentation of controlled experiments should help in confirming the "external validity" of several empirical results from experimental economics. A scientific priority is thus to improve the explanatory power of WTP models, by including factors behind social classification, consumer location and the role of major life events (retirement, etc.)

Three routes can be suggested: (a) work on larger population cohorts with more detailed information on nutrition and individual health, from which a WTP analysis could be performed repeatedly (as with the NutriNet cohort); (b) combine consumer valuation of food through WTP with approaches in psychology, social psychology and neuroscience and (c) test for features contributing to WTPs that would be associated with diet sustainability in the context of experimental online supermarkets.

\section{Research priority 2: developing interdisciplinary approaches to foster our knowledge on the complex interplay of differing diet change drivers}

A second research priority is a better understanding of the mechanisms of diet changes or inertia, and the challenges of access of quality food for all. Bringing together several disciplinary fields is necessary to address this research priority. For example, economic approaches started to explore the connections between consumer decisions, their location and the characteristics of the local food supply (Caillavet et al. 2016; Gaigné et al. 2013). Sociology of practices is addressing the question of household material 
environment (e.g. household equipment and appliances), food supply (logistics, market organization), social time patterns, household way of life, home cooking and storage skills, social norms and last, public policies (Shove et al. 2012). Research based on the theory of settlements in social psychology (Lahlou 2008) aims at understanding the role of physical space of economic agents. Foodscape and network recent approaches in geography and sociology aim at accounting for the integration of food practices of "ordinary consumers" in their geographical (for example, food deserts) and social (personal relations) environment (Morgan 2010). Combining these social science approaches and health science ones, future approaches could involve, first, epidemiologists and geographers together on the question of spatial distribution of food supply and its impact on consumer behaviour and second, nutritionists and sociologists on the role of social networks in overcoming inertia - including the role of new (digital) communication technologies. These two approaches should also be joined to address the changes, or inertia, in relation with the expanding implementation of local food policies (such as those implemented by cities involved in the Milan pact at the international scale or cities and rural regions involved in France and other countries) which both modify foodscapes and social networks. Participatory research platforms and cohorts should facilitate the implementation of the above approaches to deal with inertia in consumption practices and with new drivers of change in diets for "conventional" consumers (as opposed to the more common analysis of alternative food practices of individuals already engaged in sustainable consumption).

\section{Coordination and multi-agent governance modes to better account for health and sustainability in food systems}

Coordination and governance modes are key issues for transitions towards more sustainable food systems, that are addressed in economics, in management science and in sociology. They include agriculture and food industries' strategies, organizational determinants, contracts and regulatory instruments, certification and standards, coordination for risk management, responsibility issues and of course, public policies. Coordination in food systems is necessary for efficiency gains (lower transaction costs), product differentiation to ensure safety and traceability, information transmission about quality attributes, risk management and market power (see the literature review by Raynaud et al. 2019).

In economics, a first stream of literature considers agents' strategies in the agriculture and food industries in order to analyse the role of market structure on consumer welfare and producer profit. Such structure originates from industrial strategies of major agrofood companies and is often represented in terms of market concentration. The relationships between supply and demand can be understood from the impact analysis of demand representation on supply decisions of producers and on the strategies of agrofood firms, as illustrated by a recent stream of research in structural econometrics (see Bonnet and Bouamra-Mechemache 2016). Strategic interactions between producers and retailers can be accounted for by structural supply-demand econometric models that are estimated on individual consumer data (Bonnet and Bouamra-Mechemache 2016). These models have the capacity to distinguish between processors "and retailers" margins, thereby improving the understanding of vertical 
relationships within the agrofood industry. Coordination modes are mostly analysed from the angle of contract-based relationships (producers, suppliers, retailers) as well as the impact of merger strategies in agrofood industries on consumer welfare. While strictly speaking, health is not at the heart of merger strategies, corporate social responsibility may, however, be the source of a renewal of contract-based relationships. The latter may, for example, provide a better sharing of commercial risk in case of contamination, or of sanitary control costs (Farès and Rouvière 2010), and may in turn lead to more sustainable food chains if associated food products are obtained with more environment-friendly production modes.

For assessing the impact of merger strategies in the agrofood industry on consumer welfare, industrial economics provides useful theoretical and empirical tools. Market power of retailers in relation with the number of local competitors and anticompetitive pricing strategies can be evaluated as in Turolla (2016), as well as the impact of merger operations on consumer welfare (Allain et al. 2016; Chambolle 2017). Their results illustrate the differentiated impact of spatial price discrimination vs. uniform nationwide price strategies, on consumer surplus and markets not directly concerned with the merger, and they lead one to reconsider the definition of "relevant markets" used in the context of merger control in the agrofood industry. The above papers indicate that policies in the agrofood industry (e.g. the 1996 Galland Act in France) and economic modernization reforms may have unexpected and undesirable effects not only for consumers but also for farmers, with a significant risk of exit.

Complementary to the above research, management scientists explore organizational determinants of agents' behaviour in agrofood industries. They show for instance the way margins of action are conditioned by their production structures and routines (Nakhla 2017). In many countries, the agricultural industry is less integrated than other industries and it includes a diversity of actors operating at different levels of the supply chain (Ménard and Klein 2004). In France and other countries, the cooperatives may have a key role on the multistakeholders' coordination for tackling environmental issues because they act simultaneously at different levels of the supply chain and not only collect products but also supply farmers with inputs and services (Labarthe 2009). Agricultural cooperatives thus hold a strategic position in the sector that confer them a bargaining power and the role of a hub in the agrofood supply chain. However, in a given agricultural area, there are several cooperatives in direct competition with each other, and this competition threats their local bargaining power. The case study of the coexistence of genetically modified and conventional food reveals that these cooperatives are able to cooperate and compete at the same time (Hannachi and Coleno 2012). This cooperative "coo-petition" enables these companies to report the market's requirements to the farmers and conversely, to give feedback on farmers' constraints to the downstream industries. However, this role of farmer cooperatives and their coordination among competing farmer cooperatives is greatly upsetting the rules of competition (Ménard and Klein 2004; Labarthe 2009), and the possibility of the exemption of agricultural cooperatives from antitrust rules is still in discussion.

The impact of the implementation of production contracts or regulatory instruments (possibly associated with health and nutritional dimensions) on gains and losses for different categories of agents all along the agrofood chain is tackled by recent papers in industrial economics (Cholez et al. 2017). It is also possible to evaluate entry and exit risks for producers at various stages of agrofood chains. Such risks are conditioned 
either by private strategies for developing food products with good health or nutritional quality, or by public policies for compulsory standards or labels (see, for example, Bontemps et al. 2013; Gaigné and Larue 2016).

Recent research in sociology and management science has addressed the growing role of private certification and standards (Fouilleux and Loconto 2017), as well as "participatory guarantee systems" (Loconto and Hakanata 2017). This points to the rise of co-regulation i.e. the combination of public and private standards and beyond, market-based governance forms (Bernard de Raymond and Bonnaud 2014; Loconto 2015), in particular, about the reduction of pesticide or pharmaceutical inputs (Bonnaud et al. 2012; Fortané 2016), food security (Bernard de Raymond 2015) or nutritional risks (Déplaude 2013).

Another question concerns nutritional labelling, with the example of the Nutriscore logo, which has been validated in 2017 by French authorities (Ministry of Agriculture and Food). The fact that some actors in the agrofood industry have accepted such a label while others oppose it, raises the question not only of coordination difficulties but also of the balance of power in this industry, and requires further research.

A number of studies are dealing with the coordination of public actors and industries in terms of sanitary risk management, particularly in the case of animal breeding. Many sociological studies have explored, since the 1990s and the triggering effect of major "sanitary crises" such as the mad cow disease, the question of risk management or regulation and of traceability in the food industry (Chateauraynaud and Torny 1999; Bonnaud and Joly 2012; Granjou 2004), as well as regulations regarding pesticide and additive use (Jas and Boudia 2013). Research in animal health economics has explored risk regulation and management strategies associated with recent epizootic events (Cordier et al. 2013; Tago et al. 2016, in the case of the Foot-and-Mouth disease). These papers integrate the behaviour of cattle farmers in relation with the implementation of public policies during epizootic events. The economic analysis therein allows for an assessment of not only losses to cattle breeders but also welfare losses to consumers, at a fairly detailed geographical scale.

Interdisciplinary research has also addressed the integration of the health dimension in the agrofood industry and the related coordination issues (Magrini et al. 2017), as well as the associated technological, organizational and social innovations that pave the way for new challenges for participatory research (Desclaux et al. 2018).

The concept of responsibility and its sharing among stakeholders, associated with the development of a new "complex of requirements" (sanitary, ecological and ethical) among actors in production, retail and consumption stages, constitutes from this point of view an innovative research area (Ferreira et al. 2015). This requires taking into account, in particular, the role of "prosumers" (consumers involved in re-designing products for their own needs) in the transition of production sectors, beyond their participation in the construction of alternative food systems (Arcidiacono et al. 2018).

Research in social sciences has also dealt with the role of public policies on the reconnection between health, agriculture, food and the environment - or their disconnection at the scale of the global food system (Lang and Barling 2013). Geographers have pointed out to the necessity of developing more territorial (regional) approaches around a "new place-based food policy agenda" (Marsden and Sonnino 2012).

In France, mechanisms fostering the "agro-ecological transition" have been analysed at the regional scale, based in particular, on "sustainable transitions" or social innovation approaches. They have shown the way such mechanisms result from the commitment of 
agents in various stages of local food systems (producers, consumers, agricultural extension services, local decision-makers and stakeholders, etc.) and imply a renewed definition of their interactions and interdependencies (Lamine et al. 2015; Chiffoleau and Loconto, 2018). However, these studies focused on environmental aspects and research having health as an entry keyword remains limited (see Hannachi et al. 2019a), although some recent studies show the increasing role of urban actors in the consideration of health and the challenge of reconnecting health, agriculture, food and the environment, thereby contributing to the design of sustainable urban food systems (Brand et al. 2017), even though sanitary risks associated with urban agriculture cannot be overlooked (Aubry et al. 2015).

A last field of research in sociology of science and technology addresses the connections between knowledge production, technological innovations, organizational transformations and agents' behaviour. Applied to food studies, this field is not well developed when it comes to topics such as the impact of the generalization of nutritional qualification on world markets for processed and packaged food products (Clapp and Scrinis 2017), or the way nutrition science modifies the cultural relations to one's body in a context of diet monitoring and support (Mol 2013). Hence, this defines a key research priority (see below).

Box 2 The role of local food networks in the design of more sustainable food consumption In the last two decades, different research projects in various countries have addressed the role of local food networks, especially recently emerged ones such as collaborative associations for a "peasant agriculture" (community-supported agriculture schemes) in the enactment/demonstration of more sustainable food consumption (Dunning et al. 2015; Ilbery and Maye 2005; Lamine 2005; Sundkvist et al. 2005). In France, projects conducted at INRA (French Institute for Agricultural Research) over the past 12 years or so (such as ANR C3D, PSDR Coxinel and Casdar CODIA) also considered more conventional local food networks, such as traditional open-air markets, as potential drivers of change in a new context around food (Chiffoleau 2009). They have shown how these networks promote learning processes around sustainable agriculture and risk sharing between producers and consumers (Lamine 2005, Dubuisson-Quellier et al. 2011). This contributes to the modification of food practices, including "ordinary" consumers in the case of open-air markets, by triggering, more largely, several types of social mechanisms (learning, social control and self-esteem, see Chiffoleau et al. 2017), while generally favouring the appropriation of new norms and the reshaping of the relationship to food products. More fundamentally, these researches show, through qualitative and quantitative methods, the role of interpersonal relationships in the change in food practices, besides or beyond socio-demographic characteristics. It comes with the identification of the major steps in change trajectories, of new types of prescriptions and prescriptors within interpersonal networks, as well as of specific devices that appear as new drivers for action by mixing networks (e.g. collegial open-air markets associated with participatory labelling; Chiffoleau et al. 2016).

\section{Research priority 3: relevance of the regional/territorial scale for reconnecting health, agricultural, food and environmental challenges}

The regional/territorial scale is increasingly recognized by international institutions (OECD, FAO and UNCDF 2016), experts (IPES-Food 2018) and academics to deal 
with transition towards more sustainable food systems, yet the relevance of this scale needs to be further explored and put at test in diverse contexts. A first hypothesis is that the regional or local scale is relevant for exploring the complex of health-related issues involving agriculture, food and the environment, because such level of analysis is consistent with the diversity of agents involved, and with the interaction of social, health-related and ecological processes (Lamine et al. 2019). This assumption needs be put to the test from a comparative analysis of a variety of contrasted, rural and urban case studies. It requires a combination of qualitative approaches addressing past or ongoing transitions with modelling approaches, within an interdisciplinary perspective, as suggested in Lamine et al. (2019), Hannachi and Martinet (2019) and Hannachi et al. (2019a). A second related hypothesis is that this reconnection between health, agriculture, food and the environment requires some form of collective agreement and common understanding on these interactions and the processes they rely on. This may be based on a participatory construction of various learning and discussion approaches about the different challenges regarding food (Chiffoleau et al. 2016), or on instruments of collective thinking that combine, at the regional scale, the objectives of individual health, collective welfare and sustainable development. This would renew the approaches to assessment that are more concerned about certain types of agrofood chains (local or global, see Brunori et al. 2016) than the diversity of chains and the whole diet, and focus much more on impacts than on processes (Lamine et al. 2019). Finally, more research is needed on the role of local or territorialised public policies, beyond the case of big cities, through support to small farmholders, municipalisation of schools' food production, food procurement programmes and other innovative policy tools, for reconnecting challenges involved in the HAFEN.

\section{Research priority 4: the impact of knowledge production and technological innovations}

Several technological innovations in the agrofood industry, such as substitutes to animal products or new information technologies (development of personalized food, digitalised food practices, smart fork and fridge, 3D printers, minimal processing, etc.), already have an effect on the behaviour of actors in agrofood chains (Jönsson 2016). Recent experiments with informational or nutritional labels, as well as mobile applications providing complementary information to consumers about health impact, need to be analysed as information and coordination devices that aim at influencing not only consumer behaviour but also other agents' behaviour in agrofood chains (Frohlich 2017), while influencing interactions between actors (see Julia et al. 2017a on the French Nutriscore and Soutjis 2019 on Yuka). The long-run impact of such devices and innovations remains to be assessed. It is also necessary to analyse the effects of the emergence or circulation of new knowledge production modes (nutrition, epigenetics metagenomics, etc. but also participatory sciences), on both the (re)qualification of food products (Den Hartog 2012) and consumption practices (Mol 2013). More generally, one must understand the way agricultural and agrofood markets recompose themselves (or fail to) in relation with the rise of diverse ways of making eating conducts governable (Bergeron et al. 2016; Greenhalgh 2016). This includes further analysis of agrofood firms' strategies in terms of product labelling and marketing, accounting for firms' response to changes in consumer WTP, as discussed above. 


\section{Health-related paradigms to reshape agricultural and food systems, and associated modes of knowledge production}

This section deals with the channels through which health-related paradigms help in reshaping food systems and related knowledge production modes. Paradigms and conceptual approaches aiming at reconnecting challenges such as sustainable diets, nutrition/health sensitive agriculture, agroecology, one health and food sovereignty, are not all new, however. For example, the notion of sustainable diet has been introduced as early as the 1980s (Gussow and Clancy 1986) but has been neglected since, because of the new focus on international discussions regarding food security with a quantitative vision (Jarosz 2011), and it was only recently legitimised again, by FAO in particular (Burlingame and Dernini 2012). The notion of "nutrition sensitive agriculture", which has developed over the past years, does not deal with ecological dimensions as a priority (Balz et al. 2015). The concept of global food security is also the subject of numerous controversies and of a debate over its definition, which involves a variety of stakeholders (states, agrofood industries, and non-governmental organizations) that have put forward the notion of food sovereignty and/or food sustainability (Wittman 2011).

It is through such discussions over the definition of food security and its framework of analysis that several objectives have been re-connected and their hierarchy modified, such as health, international trade flows and the sustainability of food systems (Bernard de Raymond 2015). Over the recent period, it is around agroecology that one probably finds the most elaborated claims regarding its potential to reconnect health, agricultural, food and environmental objectives (Francis et al. 2003; Gliessman 2007; Chappell et al. 2016). However, the understanding of the processes that actually enable such a connection still needs further research, in order to move away from a situation where the convergence of ecology-consistent agricultural practices, better state of the environment and better nutritional and sanitary status of the population is taken as granted (Lamine et al. 2019).

Moreover, in the literature on reconnection and nexus approaches, welfare and health at work of farmers and agrofood industry workers are seldom accounted for. Yet, in these activities, health at work is more and more a structuring factor of the organization in the workplace (e.g. good practices in pesticide handling, stronger requirements of worker protection due to the increasing share of wage workers in agriculture, etc.) Health is, therefore, becoming an important dimension of the transformation of occupational groups (Jas 2010; Nicourt and Giraud 2013; Jouzel and Dedieu 2013). The health issue regarding agricultural workers may also be connected to the types of occupation, as a growing proportion of farm workers do not benefit from social and health benefit schemes, and are poorly informed about risks when handling pesticide products. Health at work also covers psychic or mental health of farmers (psycho-social risks, suicide, etc.; see Porcher 2003; Deffontaines 2017), which also triggers the development of new interactions among producers, citizens engaged in law suits against agroindustry corporations and consumers (Harrison 2011). While the HAFEN concept would benefit from better accounting for psychic, mental and psycho-social aspects of health, the development of research on this area is slowed down by the lack of data regarding e.g. exposure to pesticide of agricultural workers (Laurent et al. 2016). There is a risk that such research remains marginal in the future, although it is potentially a major dimension of welfare in farming and agrofood industries. 
Box 3. Introducing health in the analysis of sustainable food systems in France French scientists have developed original research on the transformation of food systems to jointly accommodate environmental and health challenges, over all stages of the food chain value. Examples include recent analyses of the effects of diversification (Meynard et al. 2013) and protein crops (Duru et al. 2017a). In the case of gluten allergy, an original approach, based on participatory science, aims at promoting and assessing the potential of local cereal systems (traditional varieties, sustainable farming, minimal processing, etc.). It succeeded in involving several actors of the agrofood industry and gluten-sensitive consumers (Desclaux et al. 2018) in a collective assessment of the health effects of cereal varieties, cropping practices, processing, packaging and consumption modes, while analysing the associated economic and organizational models that shape new territorialised food chains.

Several recent interdisciplinary projects, funded by the INRA division of plant health and the environment, have addressed the requirements for a collective and integrated management of plant health. For example, the Fondu project (durable territorial strategies for the use of fungicides) showed that the management of fungicide input on wheat and vineyards was characterized by a combination of the Tragedy of Commons (Hardin 1968) and a "Tragedy of Anti-commons" (Heller and Eisenberg 1998), a novel contribution to the literature on common goods (Hannachi et al. 2019b). Results from the "Eternal Rice" project showed that a particularly rich biodiversity in varieties of cultivated rice is securing sustainability of terrace paddy fields in YuanYang district, China. Sustainability also relies on social norms that consider seeds a common good (Hannachi and Dedeurwaerdere 2018), and whose maintenance is guaranteed when all stakeholders implement "mixed-form markets" (Marwell and McInerney 2005) by collectively targeting economic targets and non-monetary, socio-ecological welfare objectives (Dedeurwaerdere and Hannachi 2019).

\section{Research priority 5: evaluating sustainable food practices and their association with health}

Some cohort studies such as NutriNet-Santé (see Box 1) already started to investigated the relationship between specific food behaviours (such as vegetarianism, involving a lower contribution of animal products to the diet) and nutritional quality of the diet (Allès et al. 2017a), or the contribution of plant-based food and cancer (Kane-Diallo et al. 2018). However, a first current scientific challenge is to complete the standard nutritional quality of diet assessments with additional indicators, such as the contribution of ultra-processed food to the diet (Fiolet et al. 2018; Julia et al. 2017b; Schnabel et al. 2019). A second challenge for research is to explore further the impact on health and the environment of food practices associated with organic food consumption (Baudry et al. 2016) and different types of vegetarian diets, as well as the role of food environments (food deserts, concentration of retail stores, etc.) on the same nutritional and environmental dimensions. A last challenge is the capacity to develop research on the health effects of other dimensions of lifestyle (physical activity including leisure, work and commuting modes, tobacco and alcohol, etc.). This can be considered in practice by using e.g. indicators of lifestyle favouring good health (Healthy Lifestyle Index, HLI), which have been developed in epidemiology (Adjibade M. et al. 2018) but have not yet been connected to sustainable diets. Few research works are available in 
this area in the international literature, as they require the combination of several areas of expertise (epidemiology, nutrition, economics, sociology, etc.).

\section{Research priority 6: the analysis of paradigms aimed at connecting health, agriculture, food and the environment}

Many approaches claim to reconnect the main challenges of health, agriculture, food and the environment through concepts such as sustainable diets, nutrition/health sensitive agriculture, agroecology, One Health, food security and food sovereignty. The way they emerge and their influence on scientific communities and in public forums are questions that are still poorly addressed. To muster scientific disciplines and skills (food science, plant and animal science, social sciences, etc.) is necessary to conduct this analysis of the "reconnection paradigms" (see Lamine et al. 2019). More specifically, the analysis of the "Global Health" framework and of its use in public discussions and debate is a priority research topic (Koplan et al. 2009). For example, does this notion intrinsically account for farmers' and agrofood workers' health status? How is the notion made operational by various stakeholders? It is also necessary to analyse the way the narratives of public decision-makers, or citizens and private decision-makers, make use of the paradigms and concepts, combining them with possibly other references (e.g. social innovation, see Chiffoleau and Loconto 2018). This priority represents both a specific challenge in sociology and a challenge for an interdisciplinary and institutional reflection on the above paradigms.

\section{Research priority 7: social welfare analysis and policy mix when the HAFEN as a first-best solution is not feasible}

This research priority is concerned with the fact that the HAFEN can be characterized, in the words of public economists, as a "first-best" state where social welfare is maximized. However, because HAFEN requires the simultaneous achievement of different objectives (health, environment, etc.) that are interconnected for various categories of the population, such a first-best optimum is very likely not achievable in practice. Apart from the complexity behind HAFEN, the limited administrative capacity of the state may also be the reason why only a second-best solution is achievable (Bennear and Stavins 2007). While a first-best optimum can be reached only if the number of objectives and instruments are identical (Boadway and Bruce 1984), a second-best situation requires the coordination of policies to reach an efficient outcome, which involves the use of multiple-policy instruments. An important research priority is therefore to address direct and indirect effects of policies with multiple instruments targeting various dimensions of health, food and the environment in a second-best setting, where the optimal HAFEN cannot be reached.

\section{Conclusion: methodological priorities}

Based on a focused literature review and recent research projects, we have identified in this paper six key research priorities to balance, in particular, existing environmental challenges of food systems with health-related ones in a HAFEN perspective. We 
conclude with three methodological priorities that are partly linked to the aforementioned research priorities and for some of them, also generated by the rise of new opportunities provided by new data sources (new data types or renewed access modes to existing or potential data sources). They illustrate the diversity of methods that one needs to combine to address the HAFEN Nexus, beyond a genuine cross-cutting, interdisciplinary research strategy.

A first methodological priority is linked to the increasing size of databases on food purchases, diets and habits, which allows for a more accurate description of consumer choices with empirical demand models. The challenge is to enrich existing databases with a more detailed description of food items, including, for example, the environmental impact of agricultural production or consumer practices regarding cooking, food storage, etc. One may also rely on participatory approaches to perform such enrichment of existing data. Regarding social and economic aspects of access to food and social inequalities, an additional aspect of this first methodological priority concerns new and appropriate procedures for data collection, such as surveys and social experiments in urban and rural areas. In addition to collecting more and richer datasets, it is the need for innovative ways of collecting individual data on food and diets that is also at stake. The involvement of local stakeholders is essential in this regard, especially if experiments are considered on "real" consumers or on actors in food systems (such as collective catering) to explore the benefits of "equity-oriented" alternative local food systems. Similarly, another goal in this respect is to collect experimental data on food labelling at a larger and deeper scale than what is currently performed (e.g. data collection on processing modes), to calibrate demand models of consumer demand for food items produced from agro-ecological practices and minimal processing.

A second priority concerns the development of methods that combine qualitative and quantitative approaches on past or ongoing transitions in food systems with foresight studies. An example of such "hybrid" combination of approaches is the statistical analysis of text databases (from e.g. social media and networks, of bibliographical databases; see Loconto et al. 2020; Réchauchère et al. 2018 about land-use), which may be used to explore reconnection paradigms concerning health, agriculture, food and the environment. Another example is the combination of expert assessments and quantitative methods to evaluate the environmental impacts of diets, accounting for the diversity of agricultural practices and processing technologies, product or industry typologies based on quantitative (for example, Life Cycle analysis) and qualitative methods (ordinal rankings, etc.) can then be constructed and extended towards new directions, more adapted to capture the relation with health. An associated challenge is then to upscale such environmental evaluations, which would also require a better understanding and modelling of local organizations (to take into account e.g. pooling of logistic resources). A last example is the combination of multi-agent modelling with both qualitative knowledge about the new sources and contents of social influences regarding food and quantitative social networks analysis, in line with new collaborations around agent-based models (Casilli et al. 2014).

Third, for a better understanding of processes underlying the interactions between food and health within the nexus, it would be necessary to combine epidemiological and experimental methods, in order to identify causality relationships at the individual level. This is especially important in settings where randomized controlled experiments on individuals are not possible (for ethical, logistic or legal reasons), while health-food 
connections are at the core of the analysis. A combination of methods may be useful, involving, for example, individuals belonging to an observational cohort study, experiments using collective catering, virtual supermarkets, etc. An associated priority concerns the organization and interactions of actors in agrofood chains, for which an observation network should be considered as a "living lab" of various stakeholders who operate at all stages (farming, agricultural extension, processing, retailing, consumers) of an agrofood industry. To be consistent with the concept of the nexus, the latter would involve health-food issues and economic actors willing to engage in designing innovative food systems and products.

The methodological priorities above originate from the research topics proposed in the present paper, with reference to the scientific literature on food systems. These research issues and methodological priorities are primarily directed towards researchers and experts of food systems. Our suggested research issues and conclusion in terms of research priorities would greatly benefit from a feedback from public decision-makers, regarding their relevance in the light of existing public policies. Organizing communication to and feedback from public decision-makers would therefore be an interesting further step, regarding, for example, the connection with public policies associated with the development of sustainable and healthy food systems.

\section{References}

Adjibade, M., Lemogne, C., Julia, C., Hercberg, S., Galan, P., Assmann, K. E., \& Kesse-Guyot, E. (2018). Prospective association between combined healthy lifestyles and risk of depressive symptoms in the French NutriNet-Santé cohort. Journal of Affective Disorders., 238, 554-562.

Adriouch, S., Lelong, H., Kesse-Guyot, E., Baudry, J., Lampuré, A., Galan, P., Hercberg, S., Touvier, M., \& Fezeu, L. (2017). Compliance with nutritional and lifestyle recommendations in 13,000 patients with a cardiometabolic disease from the Nutrinet-Santé Study. Nutrients, 9.

Allain, M.-L., Chambolle, C., \& Turolla, S. (2016). Politique tarifaire locale ou nationale: quel impact pour le contrôle des concentrations dans le secteur de la distribution? Revue Economique, 67, 53-67.

Allès, B., Baudry, J., Méjean, C., Touvier, M., Péneau, S., Hercberg, S., \& Kesse-Guyot, E. (2017a). Comparison of Sociodemographic and nutritional characteristics between self-reported vegetarians, vegans, and meat-eaters from the NutriNet-Santé Study. Nutrients, 9, 1023.

Allès, B., Péneau, S., Kesse-Guyot, E., Baudry, J., Hercberg, S., \& Méjean, C. (2017b). Food choice motives including sustainability during purchasing are associated with a healthy dietary pattern in French adults. Nutrition Journal, 16, 58.

Andersson, H., Hammitt, J. K., \& Sundström, K. (2015). Willingness to pay and qalys: what can we learn about valuing foodborne risk? Journal of Agricultural Economics, 66(3), 727-752, September.

ANSES (2017). Etude individuelle nationale des consommations alimentaires 3 (INCA 3). Scientific expertise report. Paris.

Arcidiacono, D., Loconto, A.-M., Maestripieri, L., \& Podda, A. (2018). Introducing the wave of prosumers in the age of labour market shattering. Sociologia del Lavoro, Franco Angeli, 152, 7-22.

Aubry, C., Pourias, J., \& Daniel, A.-C. (2015). Agriculture urbaine et enjeux de santé. Cahiers de l'IAU, IAU ille-de-France, 2015, 73-74.

Bacchiega, E., Bonroy, O., \& Petrakis, E. (2018). Contract contingency in vertically related markets. Journal of Economics \& Management Strategy, 27(4), 772-791. https://doi.org/10.1111/jems.12252.

Balz, A. G., Heil, E. A., \& Jordan, I. (2015). Nutrition-sensitive agriculture: new term or new concept? Agric. Food Secur., 4, 6. https://doi.org/10.1186/s40066-015-0026-4.

Barlagne, C., Bazoche, P., Thomas, A., Ozier-Lafontaine, H., Causeret, F., \& Blazy, J. M. (2015). Promoting local foods in small states: the role of information policies. Food Policy, 57, 62-72. 
Baudry, J., Péneau, S., Allès, B., Touvier, M., Hercberg, S., Galan, P., Amiot, M. J., Lairon, D., Méjean, C., \& Kesse-Guyot, E. (2017). Food choice motives when purchasing in organic and conventional consumer clusters: focus on sustainable concerns (The NutriNet-Santé Cohort Study). Nutrients, 9, 88.

Baudry, J., Touvier, M., Alles, B., et al. (2016). Typology of eaters based on conventional and organic food consumption: results from the NutriNet-Sante cohort study. The British Journal of Nutrition, 116, 700709.

Bazoche, P., Combris, P., Giraud-Héraud, E., Seabra, P. A., Bunte, F., \& Tsakiridou, E. (2013). Willingness to pay for pesticide reduction in the EU: Nothing but organic? European Review of Agricultural Economics: doi, 41, 87-109. https://doi.org/10.1093/erae/jbt011.

Beardsworth, A., \& Keil, E. (1991). Vegetarianism, veganism, and meat avoidance: recent trends and findings. British Food Journal, 93(4), 19-24. https://doi.org/10.1108/00070709110135231.

Bennear, L. S., \& Stavins, R. N. (2007). Second-best theory and the use of multiple policy instruments. Environmental and Resource Economics, 37, 111-129.

Bergeron, H., Boubal, C., \& Castel, P. (2016). Sciences du comportement et gouvernement des conduites. In Gouverner les conduites (pp. 157-192). Presses de Sciences Po (P.F.N.S.P.).

Bernard de Raymond, A. (2015). Aligning competing risks? The UK Global Food Security programme. Risk \& Regulation, 29, 10-12.

Bernard de Raymond, A., \& Bonnaud, L. (2014). Beyond the public-private divide: GLOBALGAP as a regulation repository for farmers. International Journal of Sociology of Agriculture and Food, 21(2), 227-246.

Boadway, R. W., \& Bruce, N. (1984). Welfare economics. New York: Blackwell.

Bonnaud, L., \& Joly, N. (Éds.), (2012). L’alimentation sous contrôle. Quae, Educagri.

Bonnaud, L., Bouhsina, Z., \& Codron, J.-M. (2012). Le rôle du marché dans le contrôle des traitements phytosanitaires. Terrains \& travaux, $n^{\circ}, 20(1), 87-103$.

Bonnet, C., \& Bouamra-Mechemache, Z. (2016). Organic label, bargaining power, and profit-sharing in the French fluid milk market. American Journal of Agricultural Economics, 98(1), 113-133. https://doi. org/10.1093/ajae/aav047.

Bonroy, O., \& Constantatos, C. (2015). On the economics of labels: how their introduction affects the functioning of markets and the welfare of all participants. American Journal of Agricultural Economics, 97(1), 239-259. https://doi.org/10.1093/ajae/aau088.

Bontemps, C., Bouamra-Mechemache, Z., \& Simioni, M. (2013). Quality labels and firm survival: some first empirical evidence. European Review of Agricultural Economics, 40(3), 413-439.

Bougherara, D., \& Combris, P. (2009). Eco-labelled food products: what are consumers paying for? European Review of Agricultural Economics, 36(3), 321-341.

Brand C., Bricas N., Conare D., Daviron B., Debru J., Michel L., \& Soulard C.T. (Eds), (2017). Construire des politiques alimentaires urbaines. Concepts et démarches. Paris, Editions Quae.

Brunori, G., Galli, F., Barjolle, D., van Broekhuizen, R., Colombo, L., Giampietro, M., Kirwan, J., Lang, T., Mathijs, E., Maye, D., de Roest, K., Rougoor, C., Schwarz, J., Schmitt, E., Smith, J., Stojanovic, Z., Tisenkopfs, T., \& Touzard, J.-M. (2016). Are local food chains more sustainable than global food chains? Considerations for assessment. Sustainability, 8(5), 449. https://doi.org/10.3390/su8050449.

Burlingame, B., \& Dernini, S. (eds), (2012). Sustainable diets and biodiversity - directions and solutions for policy research and action Proceedings of the international scientific symposium biodiversity and sustainable diets united against hunger. Rome: FAO.

Caillavet, F., Kyureghian, G., Nayga, R., \& Chauvin, P. (2016). Can the rise in obesity be blamed on the food environment? Evidence from French urban data. Paper presented at the ASSA conference, San Francisco, 3-5 January 2016.

Cairns, R., \& Krzywoszynska, A. (2016). Anatomy of a buzzword: the emergence of 'the Water-Energy-Food Nexus' in UK natural resource debates. Environmental Science \& Policy, 64(October), 164-170. https://doi.org/10.1016/j.envsci.2016.07.007.

Casilli, A., Rouchier, J., \& Tubaro, P. (2014). How to build consensus in a health-oriented online community: modeling a "Pro-Ana" forum. Revue Française de Sociologie, 55(4), 731-763.

Chambolle, C., (2017). Grande distribution, règlementation et offre alimentaire. Présentation aux Etats Généraux de l'Alimentation, 20 juillet 2017, Paris.

Chappell, M. J., Moore, J. R., \& Heckelman, A. A. (2016). Participation in a City Food Security Program may be linked to higher ant alpha- and beta-diversity: an exploratory case from Belo Horizonte, Brazil. Agroecology and Sustainable Food Systems, 40(8), 804-829. https://doi.org/10.1080 /21683565.2016.1160020.

Chateauraynaud, F., \& Torny, D. (1999). Les Sombres Précurseurs: une sociologie pragmatique de l'alerte et du risque (Vol. 87). Ecole des hautes études en sciences sociales, Paris. 
Chiffoleau Y., Paturel D., Bienabe E., Millet-Amrani S., \& Akermann, G. (2020). La construction sociale de la démocratie alimentaire: quels enjeux pour la recherche? In Fourniau J.-M., Neveu C. (eds), Paris, Editions MSH, forthcoming.

Chiffoleau, Y., Akermann, G., \& Canard, A. (2017). Les circuits courts alimentaires, un levier pour une consommation plus durable ? Le cas d'un marché de plein vent. Terrains et travaux, 31, 157-177.

Chiffoleau Y., \& Loconto, A. (2018). Social innovation in agriculture and food: old wine in new bottles? International Journal of the Sociology of Agriculture and Food 24 (3), 306-317. 〈hal-01966251〉.

Chiffoleau, Y., Millet-Amrani, S., \& Canard, A. (2016). From short food supply chains to sustainable agriculture in urban food systems: food democracy as a vector of transition. Agriculture, 6(57), 1-18.

Chiffoleau, Y. (2009). From politics to cooperation: the dynamics of embeddedness in alternative food networks. Sociologia Ruralis, 49(3), 218-235.

Cholez, C., Magrini, M.-B., \& Galliano, D. (2017). Les contrats de production en grandes cultures: coordination et incitations par les coopératives. Economie Rurale, 60, 65-83.

Clapp, J., \& Scrinis, G. (2017). Big food, nutritionism, and corporate power. Globalizations, 14, 578-595.

Colombet, Z., Allès, B., Si Hassen, W., \& Méjean, C. (2019). Individual characteristics associated with changes in the contribution of plant foods to dietary intake in a French prospective cohort. European Journal of Nutrition, 58(5), 1991-2002.

Cordier, J., Gohin, A., Krebs, S., \& Rault, A. (2013). Dynamic impacts of a catastrophic production event: the foot-and-mouth disease case. Risk Analysis, 33(3), 489-492.

Croson, R., \& Treich, N. (2014). Behavioral environmental economics: promises and challenges. Environmental and Resource Economics, 58, 335-351.

Darmon, M. (2003). Devenir anorexique. Paris: La Découverte http://www.editionsladecouverte. $\mathrm{fr} /$ catalogue/index-Devenir_anorexique-9782707153753.html.

Dedeurwaerdere, T., \& Hannachi, M. (2019). Socio-economic drivers of coexistence of landraces and modern crop varieties in agro-biodiversity rich Yunnan rice fields. Ecological Economics, 159, 177-188.

Deffontaines, N. (2017). Les suicides des agriculteurs. Pluralité des approches pour une analyse configurationnelle du suicide. PhD. Thesis in sociology. Maison des Sciences de l'Homme, Dijon.

den Hartog, A. P. (2012). The discovery of vitamins and its impact on the food industry: the issue of tinned sweetened condensed skim milk 1890-1940. In Food and the City in Europe since 1800. Taylor \& Francis.

Depecker, T., Lhuissier, A., \& Maurice, A. (Éd.), (2013). La juste mesure. Une sociologie historique des normes alimentaires. Presses Universitaires de Rennes.

Depecker T., Déplaude M.-O., \& Larchet, N. (2018). La philanthropie comme investissement. Contribution à l'étude des stratégies de reproduction et de légitimation des élites économiques. Politix, n 121, p. 9-27.

Déplaude, M.-O. (2013). Une conformité par surcroît. Réception et usages des normes nutritionnelles dans le secteur agroalimentaire. In A. Lhuissier, Depecker, T. \& Maurice, A. (Éd.), La juste mesure (p. 349-371). Presses Universitaires de Rennes.

Déplaude, M.-O. (2015). Minimising dietary risk: the French association of salt producers and the manufacturing of ignorance. Health, Risk \& Society, 17(2), 168-183.

Desclaux D., Samson, M.-F., \& Chiffoleau, Y. (2018). Gluten, mythe ou réalité ? A la recherche des personnes hypersensibles. The Conversation.

Destoumieux-Garzón, D., Mavingui, P., Boetsch, G., Boissier, J., Darriet, F., Duboz, P., Fritsch, C., Giraudoux, P., Le Roux, F., Morand, S., Paillard, C., Pontier, D., Sueur, C., \& Voituron, Y. (2018). The one health concept: 10 years old and a long road ahead. Front. Vet. Sci., 5, 14. https://doi.org/10.3389 /fvets.2018.00014.

Dubuisson-Quellier, S., Lamine, C., \& Le Velly, R. (2011). Is the consumer soluble in the citizen? Mobilization in alternative food systems in France. Sociologia Ruralis, 51(3), 304-323.

Dubuisson-Quellier, S. (2016). Gouverner Les Conduites. Paris: Presses de Science-Po.

Dunning, R., Bloom, J. D., \& Creamer, N. (2015). The local food movement, public-private partnerships, and food system resiliency. Journal of Environmental Studies and Sciences, 5(4), 661-670.

Duru, M., Dedieu, B., Donnars, C., Ryschawy, J., \& Dumont, B. (2017). Quelle place pour l'élevage, les prairies et les produits animaux dans les transitions agricoles et alimentaires ? Fourrages, 232, 281-296.

Ericksen, P. J., Stewart, B., Dixon, J., Barling, D., Loring, P., Anderson, M., \& Ingram, J. (2010). The value of a food system approach. Security and Global Environmental Change, 25-45.

FAO (2010). Definition of sustainable diets. International Scientific Symposium. Biodiversity and sustainable diets united against hunger. Rome, Italy: FAO Headquarters.

Fares, M.'. H., \& Rouvière, E. (2010). The implementation mechanisms of voluntary food safety systems. Food Policy, 35(5), 412-441. 
Fassier, P., Srour, B., Raynard, B., Zelek, L., Cohen, P., Bachmann, P., Touillaud, M., Druesne-Pecollo, N., Bellenchombre, L., Cousson-Gélie, F., Cottet, V., Féliu, F., Mas, S., Deschasaux, M., Galan, P., Hercberg, S., Latino-Martel, P., \& Touvier, M. (2018 July). Fasting and weight-loss restrictive diet practices among 2,700 cancer survivors: results from the NutriNet-Santé cohort. International Journal of Cancer, 4.

Ferreira, F. R., Prado, S. D., Carvalho, M. C. d. V. S., \& Kraemer, F. B. (2015). Biopower and biopolitics in the field of food and nutrition. Revista de Nutrição, 28, 109-111.

Finkelstein, E. A., Ang, F. J. L., Doble, B., Wong, W. H. M., \& van Dam, R. M. (2019). A randomized controlled trial evaluating the relative effectiveness of the multiple traffic light and nutri-score front of package nutrition labels. Nutrients, 11(9), $\mathrm{n}^{\circ} 2236$.

Fiolet, T., Srour, B., Sellem, L., Kesse-Guyot, E., Allès, B., Méjean, C., Deschasaux, M., Fassier, P., LatinoMartel, P., Beslay, M., Hercberg, S., Lavalette, C., Monteiro, C. A., Julia, C., \& Touvier, M. (2018 February 14). Consumption of ultra-processed foods and cancer risk: results from NutriNet-Santé prospective cohort. BMJ., 360, k322.

Fischer-Kowalski, M., Jit Singh, S., Lauk, C., Remesch, A., Ringhofer, L., \& Grünbühel, C. M. (2011). Sociometabolic transitions in subsistence communities: Boserup revisited in four comparative case studies. Human Ecology Review, 18(2), 147-158.

Fortané, N. (2016). Une mobilisation contre la santé ? Les producteurs d'alcool face à la notion d'addiction. Sciences sociales et santé, 34(1), 77-101.

Fouilleux, E., \& Loconto, A. (2017). Voluntary standards, certification, and accreditation in the global organic agriculture field: a tripartite model of techno-politics. Agriculture and Human Values, 34(1), 1-14. https://doi.org/10.1007/s10460-016-9686-3.

Francis, C., Lieblein, G., Gliessman, S., Breland, T. A., Creamer, N., Harwood, R., Salomonsson, L., Helenius, J., Rickerl, D., Salvador, R., Wiedenhoeft, M., Simmons, S., Allen, P., Altieri, M., Flora, C., \& Poincelot, R. (2003). Agroecology: the ecology of food systems. Journal of Sustainable Agriculture, 22(3), 99-118.

Frazzoli, C., \& Mantovani, A. (Eds.). (2019). The environment-animal-human web: a "one health" view of toxicological risk analysis. Lausanne: Frontiers Media. https://doi.org/10.3389/978-2-88945-791-5.

Frohlich, X. (2017). The informational turn in food politics: the US FDA's nutrition label as information infrastructure. Social Studies of Science, 47, 145-171.

Gaigné, C., Frappier, L., Hilal, M., \& Parrot, L. (2013). Urbanisation et durabilité des systèmes alimentaires. In Esnouf, C., Russel, M. and Bricas, N. (Eds.), 2011. duALIne - durabilité de l'alimentation face à de nouveaux enjeux. Questions à la recherche. Inra-Cirad Report (France), 254 p.

Gaigné, C., \& Larue, B. (2016). Public quality standards and the food industry's structure in a global economy. Review of Agricultural, Food and Environmental Studies, 97(2), 141-148.

Gliessman, S.R. (2007). Agroecology. The ecology of sustainable food systems. Second Edition. CRC Press. Taylor \& Francis Group.

Goodman, D., DuPuis, E.M. \& Goodman. M.K. (2011). Alternative food networks. Knowledge, practice and politics. London: Routledge.

Gordon, L. J., Bignet, V., Crona, B., Henriksson, P. J. G., Van Holt, T., Jonell, M., Lindahl, T., et al. (2017). Rewiring food systems to enhance human health and biosphere stewardship. Environmental Research Letters, 12(10), 100201. https://doi.org/10.1088/1748-9326/aa81dc.

Gottlieb, R. (2009). Where we live, work, play and eat: expanding the environmental justice agenda. Environmental Justice, 2(1), 7-8. https://doi.org/10.1089/env.2009.0001.

Granjou, C. (2004). Le travail des experts : analyse d'un dispositif d'évaluation des risques alimentaires. Sociologie du travail, 46(3), 329-345.

Greenhalgh, S. (2016). Neoliberal science, Chinese style: making and managing the 'obesity epidemic.'. Social Studies of Science, 46, 485-510.

Gumbert, T. (2019). Anti-democratic tenets? Behavioural-economic imaginaries of a future food system. Politics and Governance, 7(4), 94-104.

Gussow, J. D., \& Clancy, K. L. (1986). Dietary guidelines for sustainability. Journal of Nutrition Education, 18, 1-5.

Hammond, R. A., \& Dubé, L. (2012). A systems science perspective and transdisciplinary models for food and nutrition security. Proceedings of the National Academy of Sciences, 109, 12356-12363.

Hannachi, M. \& Coléno, F. (2012) How to adequately balance between competition and cooperation? A typology of horizontal coopetition. International Journal of Entrepreneurship and Small Business 17(3), 273-289. 
Hannachi, M., \& Martinet, V. (2019). Vers une co-conception de paysages pour la santé des plantes et avec des acteurs du territoire. In Petit S. et al (coord.) Paysage, biodiversité fonctionnelle et santé des cultures, pp 185-234. Editions QUAE, Paris.

Hannachi, M., Berthet, E., Charrier, F., \& Coléno, F. (2019b). La transition vers une gestion durable des maladies à l'échelle du paysage. Quels apports pour les sciences de gestion et la transdisciplinarité. In Petit S. et al (coord.) Paysage, biodiversité fonctionnelle et santé des cultures. Editions QUAE, Paris.

Hannachi, M., Souchere, V., Deredec, A., Antoine, R., Han, H., Taddei, E., Berthet, E., Tonda, A., Delye, C., \& Walker, A.S. (2019a). La problématique gestion des résistances aux herbicides et fongicides : entre tragédie des communs et tragédie des anticommuns. Végéphyl - 24e conférence du Columa, Orléans -3 , 4 and 5 December 2019.

Hannachi, M., \& Dedeurwaerdere, T. (2018). Des semences en commun pour gérer les maladies. Etudes rurales, 202, 76-97.

Hardin, G. (1968). The tragedy of the commons. Science, 162(3859), 1243-1248.

Harrison, J. L. (2011). Pesticide drift and the pursuit of environmental justice. MIT Press.

Hassan, D., \& Monier-Dilhan, S. (2006). National brands and store brands: competition through public quality labels. Agribusiness, 22(1), 21-30. https://doi.org/10.1002/agr.20070.

Hassanein, N. (2003). Practicing food democracy: a pragmatic politics of transformation. Journal of Rural Sociology, 19, 77-86.

Heller, M. A., \& Eisenberg, R. S. (1998). Can patents deter innovation? The anticommons in biomedical research. Science, 280(5364), 698-701.

Hercberg, S., Castetbon, K., Czernichow, S., Malon, A., Mejean, C., Kesse, E., Touvier, M., \& Galan, P. (2010). The Nutrinet-Santé study: a web-based prospective study on the relationship between nutrition and health and determinants of dietary patterns and nutritional status. BMC Public Health, 10, 242.

Ilbery, B., \& Maye, D. (2005). Food supply chains and sustainability: evidence from specialist food producers in the Scottish/English borders. Land Use Policy, 22(4), 331-344.

IPES Food. (2015). The new science of sustainable food systems. Overcoming barriers to food systems reform (22 pages).

IPES Food. (2017). Unravelling the food-health nexus: addressing practices, political economy, and power relations to build healthier food systems (120 pages).

IPES Food, (2018). Breaking away from industrial food and farming systems: seven case studies of agroecological transition, 110 pages.

Irz, X., Mazzocchi, M., Réquillart, V., \& Soler, L.-G. (2015). Research in food economics: past trends and new challenges. Review of Agricultural and Environmental Studies, 96-1, 187-237.

Irz, X., Leroy, P., Réquillart, V., \& Soler, L. G. (2016). Welfare and sustainability effects of dietary recommendations. Ecological Economics, 130(C), 139-155.

Jarosz, L. (2011). Defining world hunger. Food, Culture \& Society, 14(1), 117-139. https://doi.org/10.2752 $/ 175174411 X 12810842291308$.

Jas, N. (2010). Pesticides et santé des travailleurs agricoles en France. Questions anciennes, nouveaux enjeux. Le Courrier de l'environnement, 59, 47-59.

Jas, N., \& Boudia, S. (Eds.), 2013. Toxicants, health and regulation since 1945. Pickering \& Chatto.

Jönsson, E. (2016) Benevolent technotopias and hitherto unimaginable meats: Tracing the promises of in vitro meat. Social Studies of Science 46, 725-748

Jouzel, J. N., \& Dedieu, F. (2013). Rendre visible et laisser dans l'ombre, make visible and leave in the shade. Revue française de science politique, 63(1), 29-49.

Julia, C., Blanchet, O., Méjean, C., Péneau, S., Ducrot, P., Allès, B., Fezeu, L.K., Touvier, M., Kesse-Guyot, E., Singler, E., \& Hercberg, S. (2016). Impact of the front-of-pack 5-colour nutrition label (5-CNL) on the nutritional quality of purchases: an experimental study. Int J Behav Nutr Phys Act. 13(1):101. doi: https://doi.org/10.1186/s12966-016-0416-4, September 20, 2016.

Julia C, Martinez L, Allès B, et al., (2017a). Contribution of ultra-processed foods in the diet of adults from the French NutriNet-Santé study. Public Health Nutr, 1-11.

Julia, C., Péneau, S., Buscail, C., Gonzalez, R., Touvier, M., Hercberg, S., \& Kesse-Guyot, E. (2017b). Perception of different formats of front-of-pack nutrition labels according to sociodemographic, lifestyle and dietary factors in a French population: cross-sectional study among the NutriNet-Santé cohort participants. BMJ Open, 7, e016108.

Kane-Diallo, A., Srour, B., Sellem, L., Deschasaux, M., Latino-Martel, P., Hercberg, S., Galan, P., Fassier, P., Guéraud, F., Pierre, F.H., Kesse-Guyot, E., Allès, B., \& Touvier, M. (2018). Association between a pro plant-based dietary score and cancer risk in the prospective NutriNet-Santé cohort. Int J Cancer. 2018 May 11. doi:https://doi.org/10.1002/ijc.31593. 
Koplan, J. P., Bond, T. C., Merson, M. H., Reddy, K. S., Rodriguez, M. H., Sewankambo, N. K., \& Wasserheit, J. N. (2009). Towards a common definition of global health. The Lancet, 373(9679), 1993-1995.

Labarthe, P. (2009). Extension services and multifunctional agriculture lessons learnt from the French and Dutch contexts and approaches. Journal of Environmental Management, 90(2), 193-202.

Lahlou, S., (2008). L'Installation du Monde. De la représentation à l'activité en situation. Psychologie. University of Provence - Aix-Marseille I. Report for the Habilitation to Supervise research. 376 pages.

Lamine, C. (2003). La Construction Des Pratiques Alimentaires Face À Des Incertitudes Multiformes, Entre Délégation et Modulation. EHESS: Le Cas Des Mangeurs Bio Intermittents. Marseille.

Lamine, C. (2005). Settling the shared uncertainties: local partnerships between producers and consumers. Sociologia Ruralis, 45, 324-345 [214].

Lamine, C. (2008). Les intermittents du bio. In Pour une sociologie pragmatique des choix alimentaires émergents (344 p). Paris: Ed. Quae/MSH.

Lamine, C. (2011). Les AMAP: Une Écologisation Négociée, Ou de Nouvelles Formes de Normalisation Inéquitables? In S. Barrey and E. Kessous (Dir.) Consommer et Protéger L'environnement. Opposition Ou Convergence?, Paris, L'Harmattan, 135-56.

Lamine, C., Bui, S., \& Ollivier, G. (2015). Pour Une Approche Systémique et Pragmatique de La Transition Écologique Des Systèmes Agri-Alimentaires. Cahiers de Recherche Sociologique, no., 58, 95-117.

Lamine, C., Magda, D., \& Amiot-Carlin, M. J. (2019). Crossing sociological, ecological, and nutritional perspectives on agrifood systems transitions: towards a transdisciplinary territorial approach. Sustainability, 11(5), 1284. https://doi.org/10.3390/su11051284.

Lang, T., \& Barling, D. (2013). Nutrition and sustainability: an emerging food policy discourse. Proceedings of the Nutrition Society, 72(1), 1-12. https://doi.org/10.1017/S002966511200290X.

Laurent, C., Baldi, I., Bernadac, G., Berthet, A., Colosio, C., Garrigou, A., Grimbuhler S., Guichard, L., Jas, N., Jouzel, J-N., Lebailly, P., Milhaud, G., Onil, S., Spinosi, J.,Lebailly, P., (2016). Expositions professionnelles aux pesticides en agriculture, Rapport final-expertise ANSES, Agence Nationale de Sécurité Sanitaire de l'Alimentation, de l'Environnement et du Travail.

Leroy, P., Requillart, V., Soler, L. G., \& Enderli, G. (2016). An assessment of the potential health impacts of food reformulation. European Journal of Clinical Nutrition, 70(6), 694-699. https://oi.org/10.1038 /ejen.2015.201.

Le Velly, R., \& Paturel, D. (2013). Des Circuits Courts Pour L'aide Alimentaire? Hybridation de Régulations Dans Un Marché Expérimental En Languedoc-Roussillon. Revue d'Études En Agriculture et Environnement, 94(4), 443-465.

Loconto, A. M. (2015). Assembling governance: the role of standards in the Tanzanian tea industry. Journal of Cleaner Production, 107, 64-73.

Loconto, A. M., Desquilbet, M., Moreau, T., Couvet, D., \& Dorin, B. (2020). The land sparing - Land sharing controversy: tracing the politics of knowledge. Land Use Policy, 96, 103610. https://doi.org/10.1016/j. landusepol.2018.09.014.

Loconto, A., \& Hatanaka, M. (2017). Participatory guarantee systems: alternative ways of defining, measuring, and assessing sustainability. Sociologia Ruralis, 58(2), 412-432.

Lusk, J. L., \& Shogren, J. F. (2007). Experimental auctions: methods and applications in economic and marketing research. Cambridge University Press.

Magrini, M.-B., Anton, M., Cholez, C., Duc, G., Hellou, G., Jeuffroy, M.-H., Meynard, J.-M., Pelzer, É., Voisin, A.-S., \& Walrand, S. (2017). Transition vers des systèmes agricole et agroalimentaire durables : quelle place et qualification pour les légumineuses à graines ? Revue Française de Socio-Économie, 18, 53-75.

Marette, S., Messéan, A., \& Millet, G. (2012). Consumers' willingness to pay for eco-friendly apples under different labels: evidences from a lab experiment. Food Policy, 37(2), 151-161.

Marsden, T., \& Sonnino, R. (2012). Human health and wellbeing and the sustainability of urban-regional food systems. Current Opinion in Environmental Sustainability, Human Settlements and Industrial Systems, 4(4), 427-430. https://doi.org/10.1016/j.cosust.2012.09.004.

Martin, S., \& Gaspard, A. (2016). Changer les comportements, faire évoluer les pratiques sociales vers plus de durabilité (183 pages). Angers: Ademe Report.

Marty, L. C., Dubois, C., Gaubard, M. S., Maidon, A., Lesturgeon, A., Gaigi, H., \& Darmon, N. (2015). Higher nutritional quality at no additional cost among low-income households: insights from food purchases of "positive deviants". American Journal of Clinical Nutrition, 102(1), 190-198.

Marwell, N. P., \& McInerney, P. B. (2005). The nonprofit/for-profit continuum: theorizing the dynamics of mixed-form markets. Nonprofit and Voluntary Sector Quarterly, 34(1), 7-28. 
Méjean, C., Si Hassen, W., Lecossais, C., Allès, B., Péneau, S., Hercberg, S., \& Castetbon, K. (2016). Socioeconomic indicators are independently associated with intake of animal foods in French adults. Public Health Nutrition, 19(17), 3146-3157.

Ménard, C., \& Klein, P. G. (2004). Organizational issues in the agrifood sector: toward a comparative approach. American Journal of Agricultural Economics, 86(3), 750-755.

Meynard, J. M, Messéan, A. Charlier, A. Charrier, F. Fares, Le Bail, M. Magrini M. B. \& Savini, I. (2013) Freins et leviers à la diversification des cultures. Etude au niveau des exploitations agricoles et des filières. Scientific expertise final report. Paris: INRA, 52.

Mol, A. (2013). Mind your plate! The ontonorms of Dutch dieting. Social Studies of Science, 43(3), 379-396. https://doi.org/10.1177/0306312712456948.

Morgan, K. (2010). Local and green, global and fair: the ethical foodscape and the politics of care. Environment and Planning A, vol., 42(8), 1852-1867.

Mouret, S. (2016). Le véganisme. Pour, 231(3), 101-107.

Nakhla, M. (2017). La conception d'une régulation par lignées génériques d'instruments. Revue Française de Gestion, 2, 51-69.

Nicourt, C., \& Girault, J.M. (2013). Viticulteurs et techniciens viticoles face à leur exposition aux pesticides. Économie rurale, $\mathrm{n}^{\circ} 333(1), 11-25$.

OECD, FAO, \& UNCDF, 2016. Adopting a territorial approach to Food Security and Nutrition Policy.OECD Publishing. http://www.oecd-ilibrary.org/urban-rural-and-regional-development/adopting-a-territorialapproach-to-food-security-and-nutrition-policy_9789264257108-en.

Paddock, J. (2017). Household consumption and environmental change: rethinking the policy problem through narrative of food practice. Journal of Consumer Culture, 17(1), 122-139.

Paturel, D., \& Ramel, M. (2017). Ethique du care et démocratie alimentaire: les enjeux du droit à une alimentation durable. Revue française d'éthique appliquée, 4, 49-60.

Péneau, S., Fassier, P., Allès, B., Kesse-Guyot, E., Hercberg, S., \& Méjean, C. (2017). Dilemma between health and environmental motives when purchasing animal food products: sociodemographic and nutritional characteristics of consumers. BMC Public Health, 17, 876.

Plessz, M., \& Etile, F. (2018). Is cooking still a part of our eating practices? Analysing the decline of a practice with time-use surveys. Cultural Sociology, 13(1), 93-118.

Plessz, M., Dubuisson-Quellier, S., Gojard, S., \& Barrey, S. (2016). How consumption prescriptions change food practices. Assessing the role of household resources and life course events. Journal of Consumer Culture, 16(1), 101-123.

Plessz, M.. \& Gojard, S. (2015). Fresh is best? Social position, cooking, and vegetable consumption in France. Sociology. Vol. 49, n¹, p. 172-190.

Plessz, M., \& Gojard, S. (2013). Do processed vegetables reduce the socio-economic differences in vegetable purchases? A study in France, European Journal of Public Health 23(5), 747-752. doi : https://doi. org/10.1093/eurpub/cks166.

Plessz, M., Dubuisson-Quellier, S., Gojard, S., \& Barrey, S. (2014). How consumption prescriptions affect food practices: assessing the roles of household resources and life-course events. Journal of Consumer Culture, 1469540514521077, 101-123. https://doi.org/10.1177/1469540514521077.

Porcher, J. (2003). Bien-Être et Souffrance En Élevage : Conditions de Vie Au Travail Des Personnes et Des Animaux. Sociologie Du Travail, 45(1), 27-43.

Raynaud, E., Bigio Schnaider, P. S., \& Macchione Saes, M. S. (2019). Surveying the economics of plural modes of organization. Journal of Economic Surveys, 33(4), 1151-1172. https://doi.org/10.1111 /joes.12315.

Réchauchère, O., El Akkari, M., Perchec, S., Makowski, D., Gabrielle, B., \& Bispo, A. (2018). An innovative methodological framework for analyzing existing scientific research on land-use change and associated environmental impacts. Sustainable Agriculture Reviews, 30, 1-13.

Régnier, F., \& Masullo, A. (2009). Obésité, goûts et consommation. Revue Française de Sociologie, 50(4), 747-773.

Schnabel, L., Kesse-Guyot, E., Allès, B., Touvier, M., Srour, B., Hercberg, S., Buscail, C., \& Julia, C. (2019). Association between ultraprocessed food consumption and risk of mortality among middle-aged adults in France. JAMA Internal Medicine, 179(4), 490-498. https://doi.org/10.1001/jamainternmed.2018.7289.

Schubert, C. (2017). Exploring the (behavioural) political economy of nudging. Journal of Institutional Economics, 13(3), 499-522.

Seconda, L., Baudry, J., Allès, B., Soler, L. G., Hercberg, S., Langevin, B., Pointereau, P., Lairon, D., \& Kesse-Guyot, E. (2018). Identification of sustainable dietary patterns by a multicriteria approach in the NutriNet-Santé cohort. Journal of Cleaner Production, 196, 1256-1265. 
Shove E., Pantzar, M., \& Watson, M. (2012). The dynamics of social practice. Everyday life and how it changes. Sage, ISBN : 9780857020420.

Soutjis, B. (2019). The new digital face of the consumerist mediator: the case of the 'Yuka' mobile app. Journal of Cultural Economy, 13(1), 114-131. https://doi.org/10.1080/17530350.2019.1603116.

Sundkvist, A., Milestad, R., \& Jansson, A. (2005). On the importance of tightening feedback loops for sustainable development of food systems. Food Policy, 30(2), 224-239.

Swee-Jin, O., Frewer, L., \& Chan, M.-Y. (2017). Cognitive dissonance in food and nutrition-a review. Critical Reviews in Food Science and Nutrition, 57(11), 2330-2342. https://doi.org/10.1080 /10408398.2015.1013622.

Tago, D., Hammitt, J. K., Thomas, A., \& Raboisson, D. (2016). The impact of farmers' strategic behavior on the spread of animal infectious diseases. PLoS One, 11(6), e 0157450.

Thaler, R.H., \& Sunstein, C.R. (2008). Nudge. Improving decisions about health, wealth, and happiness Yale University Press, New Haven, CT, 293 pages.

Turolla, S. (2016). Spatial competition in the French supermarket industry. Annals of Economics and Statistics, 121-122, 213-259.

UN (2015). Resolution adopted by the General Assembly on 25 September 2015.

Vallejo-Rojas, V., Ravera, F., \& Rivera-Ferre, M. G. (2016). Developing an integrated framework to assess agri-food systems and its application in the Ecuadorian Andes. Regional Environmental Change, 16(8), 2171-2185. https://doi.org/10.1007/s10113-015-0887-x.

Wahlen, S. (2011). The routinely forgotten character of domestic practices. International Journal of Consumer Studies, 35(5), 507-513.

Wahlen, S., \& Dubuisson-Quellier, S. (2018). Consumption governance toward more sustainable consumption. Journal of Family and Consumer Sciences, 10(1), 7-12.

Warde, A., \& Yates, L. (2017). Understanding eating events: snacks and meal patterns in Great Britain. Food, Culture and Society, 20(1), 15-36.

Wittman, H. (2011). Food sovereignty: a new rights framework for food and nature? Environ. Soc., 2, 87-105. https://doi.org/10.3167/ares.2011.020106.

Publisher's note Springer Nature remains neutral with regard to jurisdictional claims in published maps and institutional affiliations.

\section{Affiliations}

\section{Alban Thomas ${ }^{1} \cdot$ Claire Lamine $^{2} \cdot$ Benjamin Allès $^{3} \cdot$ Yuna Chiffoleau $^{4} \cdot$ Antoine $^{-}$ Doré $^{5}$ - Sophie Dubuisson-Quellier ${ }^{6}$. Mourad Hannachi ${ }^{7}$}

1 Toulouse School of Economics-Research, INRAE, University of Toulouse, 31000 Toulouse, France

2 INRAE, UR Ecodéveloppement, 84000 Avignon, France

3 INRAE, UMR EREN, University Paris-13, 93017 Bobigny, France

4 INRAE, UMR Innovation, 34000 Montpellier, France

5 INRAE, UMR Agir, 31000 Toulouse, France

6 CNRS, Centre de Sociologie des Organisations, Sciences-Po Paris, 75005 Paris, France

7 INRAE, UMR SADAPT, 75005 Paris, France 